\title{
The Influence of Additives and Different Procedures On the Viscosity of Tragacanth Mucilages
}

\author{
Kitre Zamkı Müsilajlarının Viskozitesi Üzerine Yardımcı \\ Maddeler ve Farklı İşlemlerin Etkisi \\ K. MÜNZEL* and Ş. GEÇGİ́L** \\ I N T R O D U C T I O N
}

In the literature, there exist many ingredients and methods which are used for the preparation of Tragacanth mucilages and gels(1). Besides the quality of the gum as such temperature and particle size influence the rheological properties $(2,3)$. It is known that during preparation, agitation shortens the time of gelation (4).

For the powder form of Tragacanth, starch, lactose and sugar were formulated together (5) and the effects of some ingredients on the tragacanth jellies were tested (6).

According to the literature, tragacanth in powder form mixed with sugar and used for the formulation of dry suspensions of tetracycline; the stability of these preparations was checked microbiologically (7). In this paper three different samples of Tragacanth (Sample A, B and C) have been used for the preparation of gels and besides the influence of the heating procedure that of the addition of ethanol (96\%), glycerol, propyleneglycol and sugar have been compared; furthermore the changes in viscosity were controlled over a period of three years.

Redaksiyona verildiği tarih: 6 Nisan 1977

* Pharmaceutical Research Laboratory, F. Hoffmann - La Roche and Co. AG Basel, Switzerland.

** Faculty of Pharmacy, University of Istanbul, Turkey. 


\section{EXPERIM ENTS}

MATER I A L S

1- Tragacanth Samples A, B and C.

2 - Glycerol, ethanol ( $96 \%$ ), propylene glycol and sugar pharmaceutial grade.

\section{METHODS}

1- Preparation of Gels: Eight Samples of Tragacanth gels were prepared of each of the Tragacanth samples A, B and C according to the following procedures. The amount of the gums was calculated basing on anhydrous substance. The water content was determined by heating fine powder of tragacanth at $105^{\circ} \mathrm{C}$ until a constant weight reached.

Sample 1, was prepared as follows:

An amount of Tragacanth equivalent to anhydrous $0.4 \mathrm{~g}$ Tragacanth is weighed and mixed in a tared Erlenmeyer flask with 5 g glycerol, until the gum is completely wetted and evenly dispersed over the inner surface of the flask; add $95 \mathrm{ml}$ of water containing $0.65 \%$ Nipagin and $0.35 \%$ Nipasol as fast as possible and shake. Allow to stand for one hour gently stirring at intervals of fifteen minutes. Finally content of the Erlenmeyer flask was adjusted to $100 \mathrm{~g}$.

Sample 2, was prepared by heating a part of Sample 1 in a steam bath for one hour and shaking it occasionally at intervals of 15 minutes. The weight of the sample was adjusted to $100 \mathrm{~g}$ and after storing the sample for 24 hours at room temperature the viscosity is checked.

Sample 3,5 and 7 were prepared like Sample 1, but replacing glycerol by ethanol (96\%) or propylene glycol in the same amount or by finely powdered sugar in the double amount. Suitable amounts of these samples were heated as indicated under Sample 2, thus yielding Sample 4,6 and 8 .

2- The Determination of the Water Content: The Tragacanth samples have been kept in an oven adjusted to $105^{\circ} \mathrm{C}( \pm 1)$ until the constant weight. 
3- Viscosity Measurements: The viscosity of the gels were determined by means of the Redwood No. 1 viscometer (8). The determination of the efflux times was performed according to British Pharmacopeae 1973, page 479.

RESULTS and DISCUSSION

The water content of the Tragacanth samples were shown in Table I.

Tragacanth Samples
A
13.58
12.71
12.11

Water Content $(\% \mathrm{~g})$

Table I. Percentage of water content of the Tragacanth samples $A, B$ and $C$

After preparation of the solution with the Tragacanth Sample A, B and $\mathrm{C}$ by using different procedures the corrected efflux times were measured. The results are shown in Table II.

\section{Tragacanth Samples}

$\begin{array}{cccc}\text { Tragacanth Gels } & \text { A } & \text { B } & \text { C } \\ 1 & 344.2 & 217.5 & 36.2 \\ 2 & 485.3 & 343.7 & 53.2 \\ 3 & 340.2 & 222.1 & 39.3 \\ 4 & 480.7 & 344.8 & 53.5 \\ 5 & 328.9 & 218.9 & 35.3 \\ 6 & 470.2 & 320.3 & 50.1 \\ 7 & 361.2 & 218.5 & 38.2 \\ 8 & 487.3 & 343.9 & 52.8\end{array}$

Table II. The corrected efflux times of the freshly prepared Tragacanth gels prepared from different samples and prepared by different procedures.

All the samples were kept at room temperature for 3 months, 6 months, 1 year, 2 years and 3 years and then were evaluated again. The results are given in Table III, IV and V. 


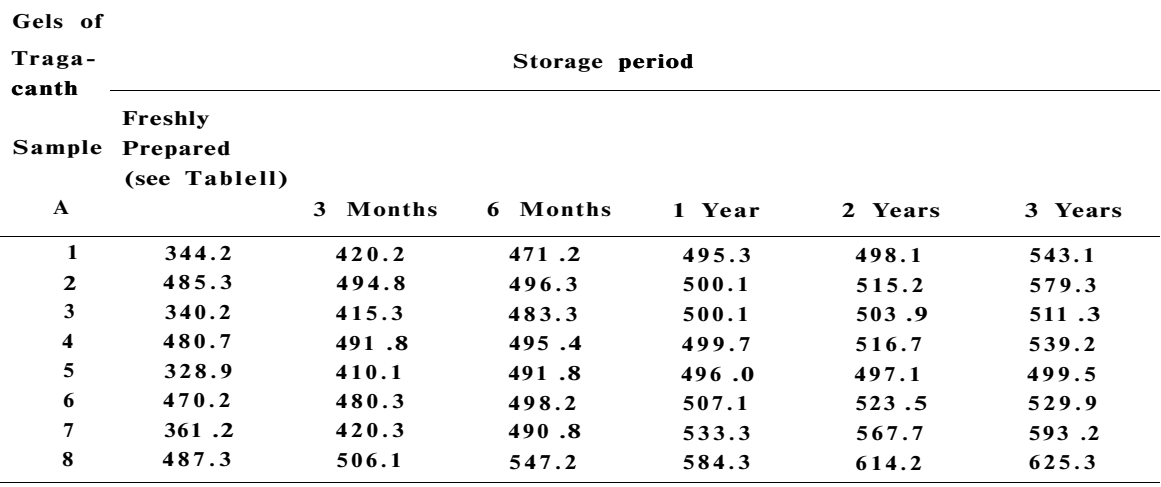

Table III. The corrected efflux times of stored gels containing Tragacanth Sample A.

Gels of

Tragacanth

Storage Period

Freshly

Sample Prepared

(see table II) 3 Months 6 Months 1 Year 2 Years 3 Years

\begin{tabular}{lllllll} 
B & & & & & & \\
\hline 1 & 217.5 & 262.5 & 286.5 & 301.2 & 314.3 & 358.2 \\
2 & 343.7 & 378.9 & 390.6 & 398.6 & 414.2 & 428.3 \\
3 & 222.1 & 259.1 & 300.7 & 309.6 & 317.3 & 360.1 \\
4 & 344.8 & 383.9 & 387.6 & 400.1 & 402.5 & 420.6 \\
5 & 218.9 & 257.2 & 300.1 & 306.6 & 309.5 & 348.2 \\
6 & 320.3 & 380.1 & 385.2 & 396.1 & 403.8 & 406.3 \\
7 & 218.5 & 281.2 & 297.3 & 319.2 & 338.3 & 359.9 \\
8 & 343.9 & 383.6 & 387.2 & 390.3 & 399.0 & 440.2 \\
\hline
\end{tabular}

Table IV. The corrected efflux times of the stored gels containing Tragacanth Sample $B$.

Gels of

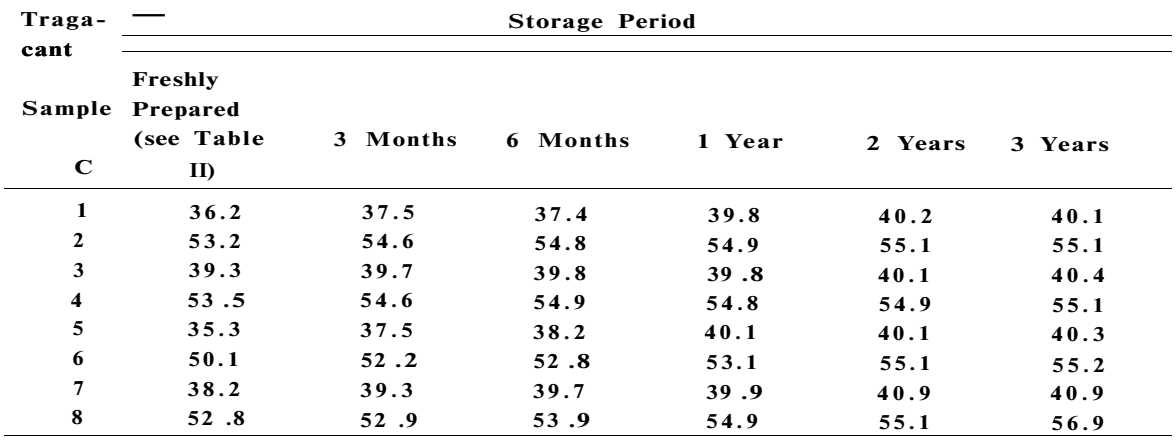

Table V. The corrected efflux times of the stored gels containing Tragacanth Sample C. 
When left standing without agitation the gels containing Tragacanth sample $\mathrm{C}$ yield a sediment on the bottom of the flaks with a clear layer above; therefore all measurements had to be controlled after shaking the samples for 5 minutes.

When gels of 3 samples of tragacanth of different viscosity were compared, the following results and the following conclusions were obtained.

1. Sample A is a Tragacanth with very high, B with medium, but still high and $\mathrm{C}$ with very low corrected efflux times resp. viscosity. Sample C does not comply with the requirement of the Brit. Ph. for apparent viscosity (at least an efflux time of 100 sec).

2. The viscosity of the mucilage samples $1,3,5$, and 7 prepared without heating one hour at $100^{\circ} \mathrm{C}$, is lower than that of the samples 2, 4, 6 and 8 with a heat treatment. In the latter samples the figures of the efflux times are higher between $36 \%$ to $58 \%$.

3. Under storage at room temperature up to 3 years, the efflux times of all mucilages are steadily increasing and generally do not yet reach a final value excepted some mucilages containing sample $\mathrm{C}$ of a very low viscosity. This demonstrates that the swelling process of Tragacanth of good quality as far as viscosity is concerned, proceeds very slowly.

4. Mucilages which are prepared by means of procedures without heating show a higher increase of efflux times during storage than those mucilages which were treated by a heating process which obviously causes a higher initial swelling of Tragacanth.

5. From a technological standpoint it is difficult to decide which agent for improving the swelling process for Tragacanth (glycerol, ethanol, propyleneglycol, sugar) is the most suitable. Sugar, however, is to be preferred for instant powders with soluble or insoluble drugs of low stability which have to be transformed into a viscous syrup or a liquid suspension by adding water just before use. If the mucilages and jellies prepared by using ethanol as wetting agent were heated, ethanol evaporates and no additive substance remains in the preparations. Therefore ethanol is regarded as convenient wetting liguid in some cases. 
6. The requirement of the Brit. $\mathrm{Ph}$. that a $0.4 \%$ Tragacanth mucilage must exhibit a corrected efflux time of not less than $100 \mathrm{sec}$ at $20^{\circ} \mathrm{C}$ in the Redwood viscometer No. 1 is justified.

In order to prepare a Tragacanth mucilage of a fixed apparent viscosity a larger amount of a powdered Tragacanth with a low viscosity has to be used than of a powder with a high viscosity. Because, however, the price of Tragacanth is regulated according to its white aspect and not to its viscosity, a powdered Tragacanth of low viscosity is uneconomic. Hence, Tragacanth should be provided with an analytical sheet indicating e. g. the efflux time of its $0.4 \%$ mucilage according to the test given in the Brit. $\mathrm{Ph}$.

\section{S U M M A R Y}

In this study; the influence of the additives and different procedures on the viscosity of Tragacanth mucilages prepared with the different Tragacanth samples which possess high, medium and low viscosity according to the method and standarts of the British Pharmacopoeia (1968) have been investigated.

The increase of the viscosity of mucilages prepared by the samples heated at $100^{\circ} \mathrm{C}$ is 36 to $58 \%$ higher than the samples prepared without heating. The influence of the additives which increase the swelling time of Tragacanth as glycerol, ethanol, propylenglycol and sugar have been compared. The most suitable additives and the conditions to use in preference for the formulas have been shown. The increase of the viscosity of all the Tragacanth mucilages after storage at room temperature up to three years have been determined. Swelling process as far as viscosity is concerned for some of the samples proceeds very slowly and does not reach a final value easily.

\section{Ö Z E T}

Bu çalışmada; ingiliz Kodeksi (1968) metod ve standartlarına göre, yüksek, orta ve düşük vizkoziteye sahip üç değişik kitre zamkı numunesinin değişik teknik ve yardımcı maddelerle hazırlanan müsilajlarının viskoziteleri ve üç yıl içinde gösterdiği değişmeler incelenmiştir. $100^{\circ} \mathrm{C}$ de bir saat isitılan numunelerin viskozitesi soğukta hazırlanan numunelere göre \% 36 ile \% 58 arasında yükselme göstermiş- 
tir. Numunelerde, kitre zamkının şişmesini kolaylaştırıcı olarak gliserin, etanol, propilenglikol ve şeker gibi yardımcı maddelerin etkisi mukayese edilmiş ve bunların tercihli olarak kullanılabilecekleri durumlar belirtilmiştir. Hazırlanan jellerin üç yıla kadar oda isısında bekletilmesi ile meydana gelen viskozite değişmeleri saptanmıştır. Kitre zamkının viskozite değişmesi olarak da tarif edilebilecek olan şişme süresi orta ve yüksek viskoziteli numunelerde yavaş yavaş artmakta ve kolayca sabit bir değere erişememektedir.

\section{REFERENCES}

1. MÜnzel, K., Büchi, J. and Schultz, O. E.: Galenisches Praktikum, Wissenschaftliche Verlagsgesellschaft $M B H$, Stuttgart 1959, page 298 and 487.

2. Vogel, H. V.: Über Wertbestimmung von Traganth und die Normung von Mucilago Unguentum Tragacanthae, Diss ETH. Zürich (1954).

3. Ory, M. A. and Steiger-Trippi, K.: Über die rheologischen Eigenschaften einiger Schleimstoffe und deren Mischungen, Pharm. Acta Helv., 39, 495 and 632 (1964).

4. Levy, G. and Schwarz, T. W.: The Relation of Method of Preparation to the Viscosity and Stability of Tragacanth Solutions, J. Amer. Pharm. Ass Sci. ed., 47, 451 , (1958).

5. Bristish Pharmacopea 1968, page 1028 .

6. Rowson, J. M.: The values of Compound Tragacanth powder as a Suspending Agent, Ğuart. J. Pharm. Pharmacol 10, 404 (1937).

7. Geçgil, Ş.: Investigations on the Preparation and the Stability of Dry Suspensions Containing Antibiotics, Journal Faculty of Pharmacy, Istanbul 2, 56 (1966).

8. Ubelohde, L.: Zur Viskozimetrie, S. Hirzel Verlag, Stuttgart 1965, page 42. 